\title{
Low-Income Housing Backlogs and Deficits "Blues" in South Africa. What Solutions Can a Lean Construction Approach Proffer?
}

\author{
James CHAKWIZIRA*1 \\ ${ }^{*}$ Corresponding author \\ ${ }^{1}$ University of Venda, School of Environmental Sciences, Department of Urban and Regional Planning, Limpopo, SOUTH AFRICA \\ E-mail: james.chakwizira@univen.ac.za, jameschakwizira@gmail.com \\ DOI: 10.24193/JSSP.2019.2.01 \\ https://doi.org/10.24193/JSSP.2019.2.01
}

\begin{abstract}
A B S T R A C T
This paper seeks to answer the following main question: "Does housing backlogs and deficits rhetoric constrain policy makers, decisionmakers, practitioners and experts from engaging in the implementation of transformative low-income housing projects and programmes in South Africa?". The aim and purpose of this paper are: (1) to contribute to the understanding of the concept of lowincome housing backlogs and deficits "blues" in South Africa. This is achieved through suggesting how innovative lean housing construction and development approach/models can play a "catalytic" role in the quest to redress low-income housing provision and delivery requirements; and (2) to argue that applied research and development of housing innovations in practice is critical in transforming the low-income housing sustainability agenda in South Africa and by extension in developing countries. The analysis is based on a critical literature review of housing approaches of low-income housing delivery, affordable strategies, policy implementation realities and discourses, low-income housing technology options, in addition to industry experience and own observation. This paper establishes the significance of considering up scaling the implementation of lean advanced construction techniques, use of low-cost building materials and fast-construction building techniques in responding to the growing demand for low-income housing provision and services in South Africa. The need to continuously monitor, evaluate and review the housing policy and regulatory set-up relevancy in addressing low-income housing deficits and backlogs with the aid of a lean construction as necessary to improve low-income housing delivery deployment in South Africa.
\end{abstract}

\section{INTRODUCTION}

The Oxford dictionary defines the word "blues" as meaning "a feeling of depression or deep unhappiness, gloominess, despondency, dejection and despair". The concept of low-income housing (LIH) and the notion of housing backlogs and deficits "blues" in South Africa is linked to a sub-optimal performing LIH sector in which slow turn-around times, slow service LIH delivery stock turnover and continued failure to reverse significantly LIH waiting list requirements persists across municipalities throughout the country. Coupled with the challenge and threat presented by climate change (CC) induced vulnerabilities for LIH with questions marks hanging with respect to the capacity and capabilities of both state and non-state actors to provide a sustainable CC resilient and insulated LIH sector in the country, so much that perceived feelings of gloom, despondency, dejection and despair start finding expression in respect to the ability of the housing sector to guarantee settlement resilience in this new climatic and socioeconomic environment. In this regard, exploring how existing initiatives such as alternative building 
technologies (ABT), lean construction (LC) could be buttressed through a $\mathrm{CC}$ resilient human settlement oriented and friendly approach becomes an exciting space for human settlement research and development (R\&D) dialogues (Smith, 2010; Howell, 2011; Goetz and Schaeffler, 2015; Bajjou and Chafi, 2019).

This paper focuses on raising questions regarding LIH debates in South Africa. The departure point of the paper is to argue that LIH debates should move beyond theorising to implementing transformative sustainable projects and programs. In the process, major roadmap research and implementation agenda are presented, which are expected to assist in going over the rhetoric's and shortcomings of current initiatives aimed at (re)solving the LIH challenge and issues in South Africa. In any case, the full cycle, structured and systematic mass scale "application of the LC approach to the construction and deployment of affordable housing (AH), can generate benefits" much greater than the ad-hoc, incremental, disjointed and fragmented current set-up (Tissington, 2011).

While some progress towards addressing LIH has been achieved since 1996, however the pace and scale were not able to wipe out housing informalities as presented in Table 1.

Table 1. Distribution of households by type of main dwelling (Census 1996 - Community survey 2016).

\begin{tabular}{|c|c|c|c|c|c|c|c|c|}
\hline \multirow{2}{*}{ Main dwelling } & \multicolumn{2}{|c|}{ Census 1996} & \multicolumn{2}{|c|}{ Census 2001} & \multicolumn{2}{|c|}{ Census 2011} & \multicolumn{2}{|c|}{ Community survey 2016} \\
\hline & Number & $(\%)$ & Number & $(\%)$ & Number & $(\%)$ & Number & $(\%)$ \\
\hline Formal dwelling & $5,834,819$ & 65.1 & $7,680,421$ & 68.5 & $11,219,247$ & 77.6 & $13,404,199$ & 79.2 \\
\hline $\begin{array}{l}\text { Traditional } \\
\text { dwelling }\end{array}$ & $1,644,388$ & 18.3 & $1,664,787$ & 14.8 & $1,139,916$ & 7.9 & $1,180,745$ & 7.0 \\
\hline $\begin{array}{l}\text { Informal } \\
\text { dwelling }\end{array}$ & $1,453,015$ & 16.2 & $1,836,231$ & 16.4 & $1,962,732$ & 13.6 & $2,193,968$ & 13.0 \\
\hline Other & 35,290 & 0.4 & 46,628 & 0.4 & 128,266 & 0.9 & 142,271 & 0.8 \\
\hline Total & $8,967,512$ & 100.0 & $11,218,067$ & 100.0 & $14,450,161$ & 100.0 & $16,921,183$ & 100.0 \\
\hline
\end{tabular}

One tenable way to tackling LIH matters in South Africa is through engaging disruptive LC and $\mathrm{ABT}$ in anchoring CC resilient settlements that do not perpetuate climate change apartheid and injustice in contemporary times. This is because the total application of LC methods, approaches and techniques will lead to the reduction of project site resource wastage, quick construction project completion times, improved quality of LIH life structures and increased profit margins for housing and building constructors. Following former President Jacob Zuma's proclamation in 2009 to change the "Department of Housing into the Department of Human Settlements" the conception of LIH was expanded from the provision of a housing unit to the planning, provision and management of spatially integrated, inclusive and resilient human settlements in which housing is nested and compliant to norms and standards linked to spatial settlement efficiency, justice, economy, resilience and good governance. These new housing ethos has roots and implications with respect to how spatial planning and settlements are (re)structured to promote spaces, places and cultures where it is a pleasure to work, live, recreate and pray for all citizens in South Africa (DEA, 2011; Zeiderman, 2016). However, it is debatable whether, to date, the intentions of such a bold measure have been fully executed or even attained. The importance of adaptive and resilient LIH is heightened in South Africa given the reality and advent of climate change induced settlement vulnerabilities linked to the risks of flooding, heat waves (temperatures) as well as the rise in the sea level (Roberts and O'Donoghue, 2013). While research and innovation with respect to $\mathrm{ABT}$ and $\mathrm{LC}$ exist, however, despite these being inadequate, worse still is the paucity of studies and work that links ABT, LC and climate change (CC) in the context of human settlements especially in South Africa. This paper therefore seeks to provide a conceptual analysis projecting how ABT, LC and CC can be linked and mainstreamed in bringing about added value to the LIH construction, deployment and sustainability framework cycle.

The Comprehensive Housing Plan (CHP) was developed with the intention of furthering the need for the development of integrated and sustainable human settlements in South Africa via the breaking new ground housing policy. The breaking new ground housing policy itself seeks, among other things, to facilitate transition and migration towards the eradication of informal settlements in South Africa in the shortest pragmatic possible time (Ndaba, 2008; Smit et al., 2011). The planned targets for transforming spatial settlements (including the provision of housing) and physical planning through seeking to achieve spatially connected, integrated and socially vibrant and dynamic human settlements act as framework guidance tools (Council for Scientific and Industrial Research, 2011). The CHP is being implemented via the informal 
settlement-upgrading (ISU) pilot projects across all provinces in South Africa (The Presidency, 2014). The ISU projects are implemented within the purview of a structured logic framework model in which clear milestones and timelines for LIH construction are adhered in compliance with agreed project phases, area-based housing development requirements, and emphasise community participation, social and economic development as essential components of any LIH projects (National Department of Human Settlements, 2015). Section 26 of the Republic of South Africa's Constitution (1996) clearly "enshrines everyone's right of access to adequate housing”. Despite the clear constitutional mandate, and "notwithstanding the provision of 2.3 million housing units to nearly 11 million people, South Africa still has a housing crisis after 24 years of democracy, with over 2.1 million households lacking adequate housing (and millions more lacking access to basic services)" (National Department of Human Settlements, 2010). Understanding the quantity of informal dwellings provides a picture of housing shortages or requirements as illustrated in Table 2, which presents the percentage of households that live in formal, informal and traditional dwellings in provinces of South Africa.

Table 2. Share of households living in formal, informal and traditional dwellings, by province, in 2018.

\begin{tabular}{|c|c|c|c|c|c|c|c|c|c|c|}
\hline \multirow{2}{*}{$\begin{array}{l}\text { Type of } \\
\text { dwelling }\end{array}$} & \multicolumn{9}{|c|}{ Province } & \multirow[b]{2}{*}{$\begin{array}{l}\text { South } \\
\text { Africa }\end{array}$} \\
\hline & $\begin{array}{c}\text { Western } \\
\text { Cape }\end{array}$ & $\begin{array}{c}\text { Eastern } \\
\text { Cape }\end{array}$ & $\begin{array}{c}\text { Northern } \\
\text { Cape }\end{array}$ & $\begin{array}{l}\text { Free } \\
\text { State }\end{array}$ & $\begin{array}{c}\text { KwaZulu } \\
\text { Natal }\end{array}$ & $\begin{array}{l}\text { North } \\
\text { West }\end{array}$ & Gauteng & Mpumalanga & Limpopo & \\
\hline Other & 1.4 & 0.5 & 0.2 & 0.1 & 0.2 & 0.0 & 1.9 & 0.0 & 0.0 & 0.8 \\
\hline Informal & 19.0 & 6.3 & 11.7 & 12.4 & 6.7 & 18.6 & 19.8 & 4,9 & 4.9 & 13.1 \\
\hline Traditional & 0.0 & 20.5 & 0.7 & 2.2 & 12.6 & 0.5 & 0.2 & 2.2 & 2.2 & 5.0 \\
\hline Formal & 79.6 & 72.8 & 87.3 & 85.2 & 80.5 & 80.9 & 78.2 & 93.0 & 93.0 & 81.1 \\
\hline
\end{tabular}

What strikes the eye is that approximately $18 \%$ of South Africans live in dwellings that are not classified as formal. Construction and building technologies e.g. Building Information Modelling (BIM) have the capacity and capabilities to ensure the optimum selection of LIH building alternatives that are able to reduce to the bare minimum possible building and construction costs and timelines while achieving optimum Leadership in Energy and Environmental Design (LEED) materials credit points (Marzouk and Metawie, 2014). The opportunity to apply advanced LIH construction methods and technologies suggests that there is a market for the developing, upgrading and improving the LIH sector delivery mechanisms. This further opens opportunities to capture the value addition that ABT and LC implementation within the context of implanting CC resilient settlements provides. The differentiated spatial footprint of informal dwellings resonates with the scale and magnitude of informal dwelling challenges between urban and rural areas as illustrated in Table 3 , which presents the percentage of households that lived in formal, informal and traditional dwellings of metropolitan areas in 2018.

Table 3. Share of households living in formal, informal and traditional dwellings, by metropolitan areas, in 2018.

\begin{tabular}{|c|c|c|c|c|c|c|c|c|}
\hline \multirow[b]{2}{*}{$\begin{array}{l}\text { Type of } \\
\text { dwelling }\end{array}$} & \multicolumn{8}{|c|}{ Metropolitan or City Area in South Africa } \\
\hline & $\begin{array}{c}\text { Nelson } \\
\text { Mandela } \\
\text { Bay }\end{array}$ & $\begin{array}{c}\text { Mangaung } \\
\text { (Formerly } \\
\text { Bloemfontein) }\end{array}$ & $\begin{array}{c}\text { eThekwini } \\
\text { (Formerly } \\
\text { Durban) }\end{array}$ & $\begin{array}{l}\text { Tshwane } \\
\text { (Formerly } \\
\text { Pretoria) }\end{array}$ & $\begin{array}{l}\text { Cape } \\
\text { Town }\end{array}$ & Ekhuruleni & $\begin{array}{c}\text { City of } \\
\text { Johannesburg }\end{array}$ & Buffalo \\
\hline Other & 1.0 & 0.5 & 0.0 & 0.0 & 1.4 & 1.7 & 3.2 & 0.7 \\
\hline Informal & 6.1 & 11.8 & 13.0 & 16.9 & 17.9 & 20.0 & 21.7 & 23.2 \\
\hline Traditional & 0.0 & 0.3 & 2.9 & 0.5 & 0.7 & 0.2 & 0.1 & 3.2 \\
\hline Formal & 92.9 & 87.5 & 84.1 & 82.6 & 80.0 & 78.2 & 75.1 & 72.8 \\
\hline
\end{tabular}

The challenge of LIH is much more pronounced once viewed in the context of the major metropolitan and city regions/areas of South Africa. This is because housing demand and supply is linked to the rapid 
urbanisation phenomena in the country and finds expression in the growth of informal settlements. Irrespective of the fact that the South African government, through the Reconstruction and Development Programme (RDP), from 1994 has been able to deliver 3 million houses, informal housing still persist today including in the backyards of the RDP houses themselves raising serious contradictions and contestations regarding whether the RDP is making a difference or is an inadequate and incomplete solution (Shapurjee and Charlton, 2013). The challenge of informal settlements is much more acute in urban areas as depicted from Table 2, since approximately $26 \%$ of the urban residents in South Africa live in informal settlements. This raises questions regarding the need to explore and investigate the feasibility of utilising alternative building technology lean construction (ABTLC) within the purview of implementing CC resilient settlements in addressing LIH matters in South Africa. Housing delivery is not just about access to a housing unit but the bundle of rights that are linked to socio-economic and legal issues is critical as illustrated in Table 4, which presents the percentage of dwelling units in 2018, by tenure status.

Table 4. Share of dwelling units, by tenure status, in 2018 .

\begin{tabular}{|c|c|c|c|c|}
\hline \multirow{2}{*}{ Occupation status } & \multicolumn{4}{|c|}{ Type of dwelling } \\
\hline & Formal & Traditional & Informal & Other \\
\hline Occupied rent free & 12.3 & 18.5 & 21.9 & 60.7 \\
\hline Owned and fully paid off & 54.2 & 74.5 & 36.5 & 9.1 \\
\hline Owned but not yet paid off & 8.3 & 0.6 & 0.4 & 0.0 \\
\hline Rented & 25.3 & 6.4 & 41.2 & 30.2 \\
\hline
\end{tabular}

Source: (Statistics South Africa, 2018).

The occupation status of housing owners is linked to security of tenure and land rights. In case occupants live in informal settlements these issues are inadequately addressed if not completely absent. This has implications on land rights and the ability of owners to develop/improve, sale or transfer rights within the property market domain.

The conceptions of housing include not only a dwelling space but entail a sense of belonging as well as start-up kit to access and engage with the wider environment and world (Ballard, 1999; Dayaratne and Kellett, 2008; Myers, 2016). The informal housing sector is complex but riddled with its own set of "wicked problems" that requires careful unpacking to address, as depicted in Table 3. Options and housing packages mixes that are able to provide low-cost, adaptive structures via the ABTLC with full consideration of the CC vulnerabilities are worth pursuing and implementing. The structural quality of LIH is crucial as these are vulnerable groups that have low adaptive capacity in the event of a disaster affecting their structures; hence, Table 5 presents the percentage of households that were of the opinion that their Reconstruction and Development Programme (RDP) or state-subsidised houses have weak or very weak walls and/or roof.

Table 5. Share of households declaring that their 'RDP' or state-subsidised houses have weak or very weak walls and/or roof, by province, in 2018.

\begin{tabular}{|c|c|c|c|c|c|c|c|c|c|c|}
\hline \multirow{2}{*}{$\begin{array}{l}\text { Owner/Occupier } \\
\text { perception of } \\
\text { RDP or } \\
\text { subsidised unit }\end{array}$} & \multicolumn{9}{|c|}{ Province } & \multirow[b]{2}{*}{$\begin{array}{l}\text { South } \\
\text { Africa }\end{array}$} \\
\hline & $\begin{array}{l}\text { Western } \\
\text { Cape }\end{array}$ & $\begin{array}{l}\text { Easter } \\
\text { Cape }\end{array}$ & $\begin{array}{l}\text { Northern } \\
\text { Cape }\end{array}$ & $\begin{array}{l}\text { Free } \\
\text { State }\end{array}$ & $\begin{array}{c}\text { KwaZulu } \\
\text { Natal }\end{array}$ & $\begin{array}{l}\text { North } \\
\text { West }\end{array}$ & Gauteng & Mpumalanga & Limpopo & \\
\hline $\begin{array}{l}\text { Walls - weak or } \\
\text { very weak }\end{array}$ & 16.2 & 7.6 & 10.4 & 13.7 & 11.9 & 6.1 & 3.6 & 7.9 & 8.9 & 9.1 \\
\hline $\begin{array}{l}\text { Roof - weak or } \\
\text { very weak }\end{array}$ & 15.8 & 8.5 & 7.9 & 12.1 & 13.9 & 3.5 & 3.9 & 8.2 & 9.5 & 9.1 \\
\hline
\end{tabular}

Source: (Statistics South Africa, 2018).

While perception on structural quality and soundness of LIH requires a full cycle analysis by structural engineers, a perception survey or opinion of residents/occupiers can also provide a good sense of the structural sturdiness of LIH as viewed by the occupants/residents. LIH envisages the conception and deployment of advanced and appropriate budgeting, cost reduction, building and construction techniques through use of locally available materials and the 74 prudent application of skills and technologies without compromising the housing units' strength, performance and life of the structure (Bredenoord, 2017; Foong et al., 2017; Ganiyu, 2016; Holweg, 2007; Howell, 2011; Tam, 2011; Salem et al., 2006; Van Damme and Houben, 2018). Overall, approximately $10 \%$ of LIH RDP or state subsidised structures perceive such structures as either having structural defects or inadequacies with respect to walls and roofs. This 
paints a worrying housing portrait in a context in which CC vulnerabilities linked to flooding and temperature increase likelihood of hazards to settlements. Research and development work with respect to ABTLC and CC adaptive structures becomes an important dimension in the quest to advance sustainable LIH provision and maintenance in South Africa.

Despite the afore-mentioned issues, South Africa's human development goals for sustainable lowcost human housing settlements are consequently enunciated in instructive strategy and policy documents such as Agenda 21 (1992), the Habitat Agenda (1996), the Millennium Declaration (2000), the outcomes of the World Summit (2002), White Paper on Housing (1996), Breaking New Ground (2004) to name a few (Department of Housing, 1994, 2000, 2004). The principles, concepts, and philosophy enshrined by such related documents can be distilled to generate a set of low-cost sustainable housing performance indicators (Chakwizira and Bikam, 2007; Ross et al., 2010). At the same time a 360 degree review of similar and related policy, strategy, and action documents will point to $\mathrm{LIH}$ contestations and dialogues that have roots linking to rhetoric's, rubrics, and implementation bottlenecks. This paper seeks to expand the knowledge domain on how innovative lean housing construction and development approach/models can play a "catalytic" role in the quest to redress LIH housing backlogs and deficits "blues" in South Africa.

\section{THEORY AND METHODOLOGY}

The paper employs a dynamic system, ABT via life cycle assessment (LCA), CC and LC theoretical approach and methodology in unpacking the LIH backlogs and deficits "blues" in South Africa (Azar, 2012; Caruso et al., 2017; Chévez et al., 2019; Fewings and Henjewele, 2019; Nguyen et al., 2016). These theoretical lenses are complemented by thematic analytical technique with respect to desktop studies and analysis of secondary data, including reviewing case studies in LIH in South Africa.

A systems dynamic approach gives the advantage of analyzing the housing sector holistically taking into account all the sub-components that constitute the housing sector as a system. At the same time, the LC theoretical frame provides measurement indicators for assessing the level of adoption, access, and replication of low-cost and alternative housing technology (AHT) uptake for resolving LIH issues. In addition, key informants from the Department of Human Settlements (DoHS), Provincial Departments of Local Government and Housing (South Africa) as well as the South African Local Government Association (SALGA) and the South African Cities Network (SACN), the Council for Scientific and Industrial Research
(CSIR) and Universities in South Africa with housing, architecture, planning, and human settlements qualifications were also consulted. The synthesis of the outcome of findings was used in compiling this paper.

\subsection{Conceptual framework}

A survey of both national and international literature reveals that several theories, approaches, models, and interventions can be utilised in addressing LIH needs (Huang, 2012; Ibem and Aduwo, 2013; Phengand Meng, 2018). These range from centralised models that are state-driven to decentralised models that are driven by non-state sectors with the state playing a facilitator role. In addition, different hybrid models that allow both the state and non-state sectors to respond to LIH changing needs exist. Figure 1 summarises the housing approaches based on pools and the flow including the contestation paradigm that relate to LIH delivery and provision.

LIH is a complex, dynamic and highly contested area - be it from a policy, research or practice perspective. Dialogues and conversations play out regarding how best LIH can be advanced in a low-cost but effective manner that stems out the possibility of service delivery protests linked to housing delivery under-performance. LIH backlogs and deficits contestations relate to where low-income areas are located, usually in relation to workplaces, the cost of affording approved building materials that is usually high, (no)compliance with stringent building codes, inadequate consultation and participation of housing beneficiaries, etc. (as depicted in Figure 1). These complex factors play out in terms of LIH deficits and shortages, with implications on service delivery for municipalities and housing stakeholders.

\subsection{LC and LIH overview in South Africa}

In LIH housing provision, the production management component is crucial in minimizing overhead project construction and building operational and management costs, and also in eliminating wastage and spillage of resources on site (Souza, 2004; Martinez, 2016). The concept of LC has its origins in the early 1990s (Koskela, 1992; Holweg, 2007; Oguntona et al., 2019). It is based on adapting, adopting and deploying the Toyota Production System (TPS) in the project management of housing building and construction projects (Antunes and Gonzalez, 2015). LC and manufacturing describe the application of TPS concept focused on identifying and eliminating waste and facilitating continuous product improvement for either processes or products (Womack et al., 1990; Suh et al., 2015; Rane et al., 2016). In any case, "Lean Thinking" is linked to "lean thinking principles", namely building and construction norms and standards 
(i.e. values, value addition, the value stream, flow, pull, and perfection (Salem et al., 2006; Schroeder, 2014; Koskela et al., 2018; Moaveni et al., 2019). Koskela (1992) popularised the adoption of TPS and lean manufacturing in civil engineering and construction management (Pekuri et al., 2014; Schroeder, 2014; Vinodh et al., 2015). Ballad (2000) describes the "Last Planner System (LPS)" as a technique applicable to the construction sector through enabling project variables to support effective and efficient building construction and management structured workflow protocol (Ballard, 1999; Daniel et al., 2017; Durakovic et al., 2018). Invariably, the domestication of LC concepts, techniques and tools within the LIH projects/ programmes and activities necessary for the provision of the least costs, accessible and affordable housing in South Africa. Consequently, this paper provides a conceptual framework for locating LIH via the ABTLC taking into account $\mathrm{CC}$ adaptive and resilient settlements needs for South Africa.

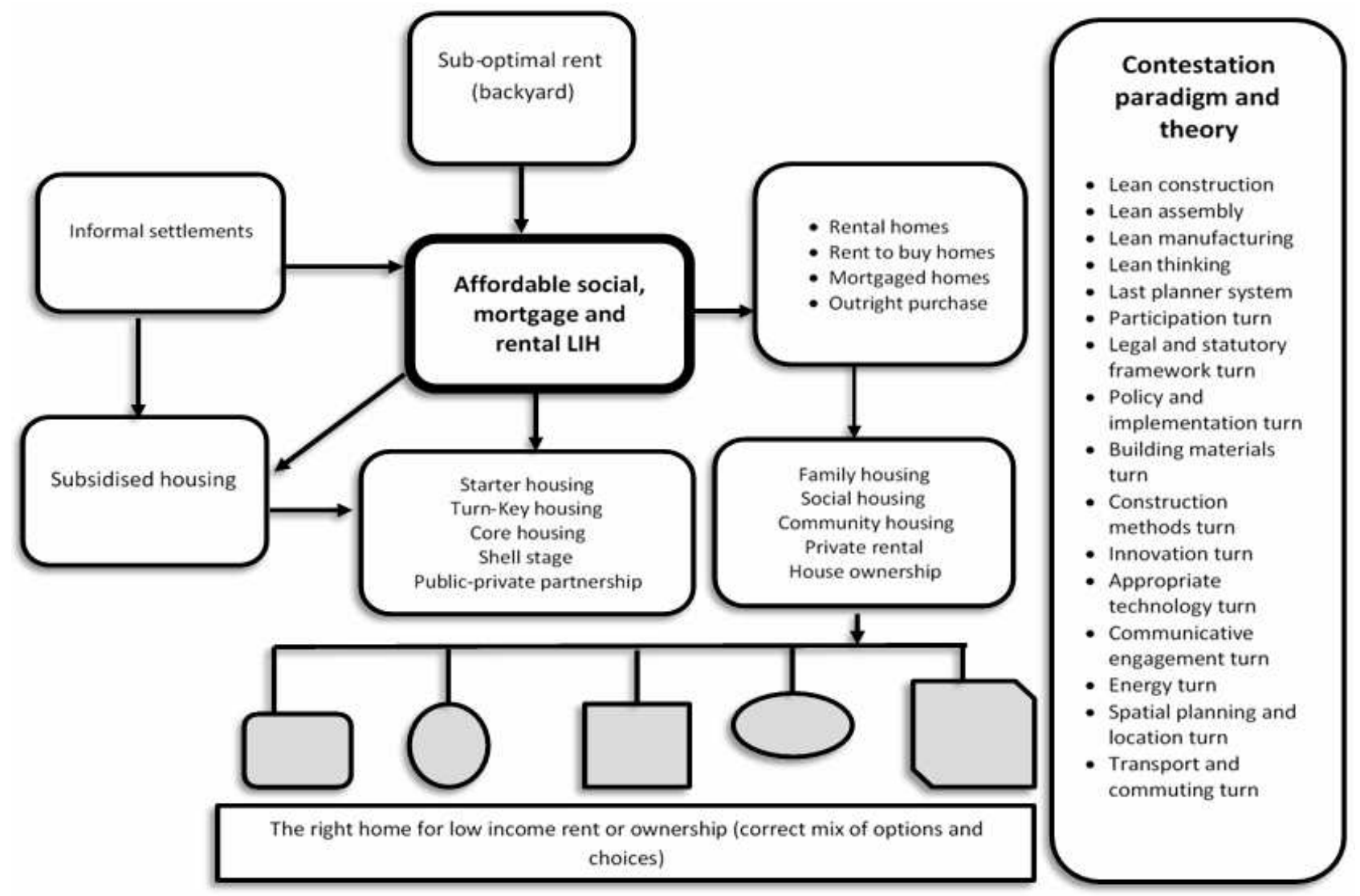

Fig. 1. An LIH delivery approach based on pools and flows depicting contestations.

\section{RESULTS AND DISCUSSION}

This section presents the results and a discussion on the importance of the study findings within the broad human settlement and spatial planning disciplines.

\subsection{The policy implementation turns in South Africa - National LIH construction landscape overview}

According to the "2009 General Household Survey prepared by Statistics South Africa (Stats SA, 2009), about $12.8 \%$ of the South African households live in a RDP or state-subsidised dwelling and $13.5 \%$ of households have at least one household member on a demand database or waiting list for state subsidised housing" (Stats SA, 2009). An overview of estimates, with respect to the requirements for the need to provide adequate shelter in South Africa highlighting and making use of the housing backlog, from 1994 to 2009 as a case in point, is presented in Table 6.

Studies have calculated that approximately R80o billion is required to eradicate the housing backlog in South Africa by 2020 (Pillay, 2017; Msindo, 2017). Tackling run-away housing backlogs/deficits as reflected in Table 5, is challenging, demanding and exciting. The housing backlog is approximately above 2.1 million and has remained what has virtually been termed a moving average, which is currently estimated at 2.3 million (Msindo, 2017). Addressing this LIH backlogs entail adopting steps that have implications with respect to massive investment in appropriately sited and located LIH developments that are 
Low-Income Housing Backlogs and Deficits "Blues" in South Africa.

What Solutions Can a Lean Construction Approach Proffer?

Journal Settlements and Spatial Planning, vol. 10, no. 2 (2019) 71-88

constructed by making use of appropriate, innovative and robust housing technologies and approaches in an effort to avert the upward trajectory in housing backlog growth in the country.

\subsection{South Africa's provincial informal dwellings challenge overview}

In the mid-2009, $13.4 \%$ of households in South Africa lived in informal dwellings (Stats SA, 2007).
Housing backlog is clearly linked to the country's basic services backlog, which includes lack of access to water, sanitation, electricity and refuse removal. Migration and natural population growth in cities and major settlement nodes, together with low LIH units outputs delivery, explains largely the mismatch between housing stock units delivery and supply side constraints.

Table 6. Need for adequate shelter estimates (housing backlog) - 1994 to 2009.

\begin{tabular}{|c|c|c|c|c|c|c|c|c|c|c|}
\hline $\begin{array}{c}\text { Financial } \\
\text { year }\end{array}$ & $\begin{array}{l}\text { Eastern } \\
\text { Cape }\end{array}$ & $\begin{array}{l}\text { Free } \\
\text { State }\end{array}$ & Gauteng & $\begin{array}{c}\text { KwaZulu- } \\
\text { Natal }\end{array}$ & Limpopo & Mpumalanga & $\begin{array}{l}\text { Northern } \\
\text { Cape }\end{array}$ & $\begin{array}{l}\text { North- } \\
\text { West }\end{array}$ & $\begin{array}{l}\text { Western } \\
\text { Cape }\end{array}$ & $\begin{array}{l}\text { South } \\
\text { Africa } \\
\text { Total } \\
\end{array}$ \\
\hline 1994/1995* & - & - & - & - & - & - & - & - & - & - \\
\hline 1995/1996* & - & - & - & - & - & - & - & - & - & - \\
\hline 1996/1997 & 309,791 & 181,963 & 472,564 & 345,200 & 141,548 & 126,875 & 28,421 & 174,512 & 165,461 & $1,946,336$ \\
\hline 1997/1998* & - & - & - & - & - & - & - & - & - & - \\
\hline 1998/1999* & - & - & - & - & - & - & - & - & - & - \\
\hline 1999/2000* & - & - & - & - & - & - & - & - & - & - \\
\hline $2000 / 2001$ & - & - & - & - & - & - & - & - & - & - \\
\hline $2001 / 2002$ & 330,000 & 220,000 & 750,000 & 400,000 & 120,000 & 145,000 & 35,000 & 240,000 & 230,000 & $2,470,000$ \\
\hline $2002 / 2003$ & 339,200 & 133,900 & 461,000 & 379,700 & 104,500 & 123,400 & 12,000 & 124,500 & 172,000 & $1,850,000$ \\
\hline $2003 / 2004$ & 336,700 & 144,400 & 536,000 & 362,200 & 105,400 & 116,100 & 17,000 & 100,800 & 201,000 & $1,919,600$ \\
\hline $2004 / 2005$ & 388,500 & 201,300 & 556,300 & 395,000 & 124,600 & 126,400 & 17,000 & 95,900 & 213,000 & $2,118,800$ \\
\hline $2005 / 2006$ & 352,600 & 169,000 & 697,950 & 533,200 & 112,800 & 132,500 & 32,200 & 222,100 & 222,850 & $2,475,200$ \\
\hline $2006 / 2007$ & 265,700 & 208,000 & 628,000 & 400,000 & 153,000 & 153,000 & 48,500 & 220,000 & 403,500 & $2,479,700$ \\
\hline $2007 / 2008$ & 240,000 & 165,000 & 619,500 & 372,200 & 122,400 & 137,500 & 38,000 & 210,500 & 378,700 & $2,283,800$ \\
\hline $2008 / 2009$ & 235,000 & 160,000 & 615,000 & 365,000 & 110,000 & 128,000 & 34,000 & 202,000 & 305,000 & $2,154,000$ \\
\hline
\end{tabular}

Source: (National Department of Human Settlements, 2015).

Table 7. Distribution of household by the main dwelling, per province (2007).

\begin{tabular}{|c|c|c|c|c|}
\hline $\begin{array}{l}\text { Province (total number } \\
\text { of households) in } 2007\end{array}$ & $\begin{array}{l}\text { Share living in informal } \\
\text { dwelling - shack in } \\
\text { backyard (no. of } \\
\text { households) }\end{array}$ & $\begin{array}{l}\text { Share living in informal } \\
\text { dwelling - shack NOT in } \\
\text { backyard i.e. in an } \\
\text { informal settlement (no. } \\
\text { of households) }\end{array}$ & $\begin{array}{l}\text { Share living in worker's } \\
\text { hostel (no. of households) }\end{array}$ & $\begin{array}{c}\text { Share living in } \\
\text { traditional } \\
\text { dwelling/hut/structure } \\
\text { made of traditional } \\
\text { materials (no. of } \\
\text { households) }\end{array}$ \\
\hline Gauteng $(3,175,579)$ & $8.4 \%(266,749)$ & $14.3 \%(454,108)$ & $3.1 \%(98,442)$ & $0.4 \%(12,702)$ \\
\hline $\begin{array}{l}\text { KwaZulu-Natal } \\
(2,234,129)\end{array}$ & $2.3 \%(51,385)$ & $6.3 \%(140,750)$ & $3.2 \%(71,492)$ & $27.4 \%(612,151)$ \\
\hline Western Cape $(1,369,180)$ & $6.2 \%(84,889)$ & $8 \%(109,534)$ & $1 \%(13,691)$ & $0.8 \%(10,963)$ \\
\hline Eastern Cape $(1,586,739)$ & $1.6 \%(25,388)$ & $6.4 \%(101,551)$ & $0.2 \%(3,173)$ & $36.7 \%(582,333)$ \\
\hline Limpopo $(1,215,935)$ & $1.9 \%(23,103)$ & $3.6 \%(43,774)$ & $2 \%(24,318)$ & $9 \%(109,434)$ \\
\hline Mpumalanga $(940,403)$ & $2.5 \%(23,510)$ & $9.2 \%(86,517)$ & $3.3 \%(31,033)$ & $7 \%(65,828)$ \\
\hline North West $(911,120)$ & $7.8 \%(71,067)$ & $16 \%(145,779)$ & $7 \%(63,778)$ & $2.3 \%(20,955)$ \\
\hline Free State $(802,872)$ & $4.9 \%(39,341)$ & $13.6 \%(109,190)$ & $5.7 \%(45,763)$ & $4.6 \%(36,932)$ \\
\hline Northern Cape $(264,653)$ & $1.6 \%(4,234)$ & $8.9 \%(23,554)$ & $4 \%(10,586)$ & $4.5 \%(11,902)$ \\
\hline South Africa $(12,500,610)$ & $4.7 \%(587,529)$ & $9.7 \%(1,212,559)$ & $2.9 \%(362,517)$ & $11.7 \%(1,462,571)$ \\
\hline
\end{tabular}

Source: (National Department of Human Settlements, 2015).

Consequently, instead of witnessing a decline in housing demand, there is always a statistically significant increase in the percentage of households that lived in informal dwellings especially in the major metropolitan areas of South Africa such as Johannesburg, Cape Town and eThekwini (formerly
Durban). The statistical distribution of households by the main dwelling type, provided by Stats SA's 2007 Community Survey" is presented below in Table 7 (Stats SA, 2007).

Housing backlogs and deficits manifest themselves in terms of inappropriately located LIH 
informal settlements as well as in the densification of existing LIH settlements in response to rapid urbanization determined by rural to urban migration in South Africa. Given the reality of urbanization, housing and related challenges in South Africa, as resulted from Table 7 , we can deduce that with $4.7 \%$ representing informal shacks in the backyards of formal residential stands, with bulk infrastructure implications for service delivery. This is because formal areas have to respond and provide services and facilities beyond the planned capacity, thus creating pressure and stress on existing facilities such as water, sewer, transport, schools, health facilities etc. At the same time, a further significant share of $9.7 \%$ (stand-alone informal structures) exists, further exacerbating the capacity and ability of municipal infrastructure and systems to respond to the rapid urbanization needs of such settlements. This raises the question as to whether the municipal governments and planning systems in South Africa are adequately prepared or are ill-prepared to manage and respond to the current wave of urbanization engulfing the country in contemporary times. In any case, some 2.9\% of the urban residents in South Africa are living in worker's hostels and $\mathbf{1 1 . 7 \%}$ of the households are categorised as traditional dwelling/structures.

Considering the preceding discussion, there is little wonder that in fact, by 2010, the Minister of Human Settlements expressed concern with respect to the fact that the "number of informal settlements has increased to more than 2,700, containing a total of approximately 1.2 million households in 2010" (National Department of Human Settlements, 2010). LC presents an opportunity to address housing deficits and backlogs as it improves the rate of turnover in delivering housing units, adopting housing technology and construction methods that reduce land needs, construction assembly processes and workflow constraints and waste (Womack et al., 1990; Koskela, 1992; Smith, 2014; Lee et al., 2017).

\subsection{Housing delivery and performance implementation turn in South Africa}

Gauging housing delivery through an analysis of demand and supply provides the opportunity to track progress and raise questions regarding performance with respect to LIH settlement planning and management strategies, efficiency and effectiveness. Addressing housing shortage delivery can be approached from a reactive or proactive perspective, as illustrated in Table 8, which "shows the preliminary units delivered in 2009/10 and estimated delivery until 2014. If delivery occurred at this pace - on average of 230,000 units per year (which is unlikely) - it would mean that by 2014 approximately 1.1 million housing units would have been delivered" (National Department of Human Settlements, 2010).

The worrying statistics with respect to such a scenario is that if a business as usual (BAU) picture as portrayed here is retained, then there would be over 1 million units short of the current and growing backlog of 2.1 million households, which is a conservative estimate. In order to address this, in terms of a business unusual (BUU) approach, disruptive ABT, LC and CC adaptive and resilient LIH settlement systems and programmes should be rolled out in the country.

Table 8. Estimated housing delivery from 2008 to 2014 (units).

\begin{tabular}{|c|c|c|c|c|c|}
\hline \multirow{2}{*}{ Province } & \multirow{2}{*}{$\begin{array}{c}\text { Preliminary } \\
\text { delivered 2009/2010 }\end{array}$} & \multicolumn{4}{|c|}{ Estimated delivery } \\
\hline & & $2010 / 2011$ & 2011/2012 & $2012 / 2013$ & $2013 / 2014$ \\
\hline Eastern Cape & 28,633 & 23,400 & 23,400 & 24,463 & 26,058 \\
\hline Free State & 18,829 & 21,462 & 21,462 & 22,438 & 23,901 \\
\hline Gauteng & 39,922 & 48,553 & 48,553 & 50,760 & 54,071 \\
\hline KwaZulu-Natal & 27,376 & 26,626 & 26,626 & 27,837 & 29,652 \\
\hline Limpopo & 23,079 & 22,613 & 22,613 & 23,641 & 25,182 \\
\hline Mpumalanga & 8,291 & 8,181 & 8,181 & 8,553 & 9,111 \\
\hline Northern Cape & 6,257 & 6,512 & 6,512 & 6,808 & 7,253 \\
\hline North West & 35,141 & 30,954 & 30,954 & 32,361 & 34,472 \\
\hline Western Cape & 32,371 & 31,698 & 31,698 & 33,139 & 35,300 \\
\hline Total & 219,899 & 220,000 & 220,000 & 230,000 & 245,000 \\
\hline
\end{tabular}

Arresting housing backlogs and deficits requires the implementation of a LIH turn-around strategy that creates spaces for state and non-state actors to contribute towards LIH delivery and provision. Within the confines of either exponential or logarithmic growth, as depicted from Table 8, we can deduce that the "housing backlog has grown exponentially since 1994 and continues to increase partly due to change in household structures, rapid urbanisation, migration to cities and large towns, lack of opportunities in rural areas, structural unemployment, more households falling into the subsidy income band and less access to 
housing finance" (Reddy, 2016). The DHS recently stated, in a parliamentary portfolio committee workshop, that "it is moving away from the use of the term" "backlog", as the "term is time-specific, and urbanisation/migration makes quantification of housing backlogs problematic" (The Presidency, 2014). Instead, the DHS now refers to "housing needs" and the "investment required to provide for these needs" (Tshangana, 2018). In this new LIH paradigm approach, the scope and role that ABTLC, within the context of a CC adaptive and resilient settlement framework, cannot be over-emphasised.

3.4. LIH lean construction, alternative, and appropriate technology turn: what is practice offering for theory in South Africa

Literature is replete with how ABTLC and CC adaptive and resilient settlement systems can be a powerful antidote in addressing LIH settlements challenges and matters (Ashworth and Perrera, 2015; Bajjou et al., 2017; Ballard and Rubin, 2017; Bredennoord, 2017). Infusing disruptive LIH construction and building technologies, as depicted in Table 9, presents opportunities for changing the LIH projects landscape in terms of $\mathrm{ABT}$ implementation issues. ABT and LC present opportunities for implementing spatial transformative housing projects in South Africa, taking into account location, sitting and the need to address the spatial fragmentation induced problems in South Africa. Indeed, LC and ABT hold prospect for changing and transforming the LIH landscape and architecture, as highlighted in Table 9, since we can deduce the existence of LIH appetite for lean construction, despite visible constraints to the massification of such approaches.

These constraints are linked to change management challenges as well as the tight profit margins of the construction industry. These issues make experimenting new ideas not favourable.

Table 9. LIH projects in terms of LC and ABT implementation.

\begin{tabular}{|c|c|c|}
\hline LIH Technologies & Application & Observation \&comments \\
\hline $\begin{array}{l}\text { Government support for } \\
\text { LIH alternative building } \\
\text { and construction } \\
\text { technology initiatives }\end{array}$ & $\begin{array}{l}\text { In } 2007 \text {, the "National Home Building Regulation } \\
\text { Council (NHBRC) was mandated" to provide leadership } \\
\text { in exploring new designs (i.e. quality, appearance, and } \\
\text { affordability). } \\
\text { The utilisation of LC and alternative building } \\
\text { technologies in government housing projects inadequate } \\
\text { and skewed towards Gauteng Province }\end{array}$ & $\begin{array}{l}\text { Support and promotion of innovators to showcase ABT or } \\
\text { innovative systems by Eric Molobi Innovation Hub in } \\
\text { Soshanguve } \\
\text { Uptake of ABTLC slow and sporadic (Salem et al., 2006) }\end{array}$ \\
\hline $\begin{array}{l}\text { 2003: State of LIH } \\
\text { Technologies } \\
\text { application }\end{array}$ & $\begin{array}{l}\text { High uptake and usage of compressed earth blocks } \\
\text { (CEB), interlocking blocks (IB), shutters and concrete } \\
\text { (SAC), everite fibre cement blocks (FCB)and eco-frame } \\
\text { building materials (EBM) }\end{array}$ & $\begin{array}{l}\text { Policy, municipal by-laws and general building } \\
\text { regulations do not prohibit the use of ABTLC in } \\
\text { government housing development projects (Du Plessis, } \\
\text { 2005). } \\
\text { Trials and pilot projects in ABTLC have not resulted in } \\
\text { large scale commercial production and uptake of such } \\
\text { technologies }\end{array}$ \\
\hline $\begin{array}{l}\text { Between } 1994 \text { and } 2010 \\
\text { about } 2.8 \text { million } \\
\text { housing units were } \\
\text { delivered for low- } \\
\text { income earners }\end{array}$ & $\begin{array}{l}\text { Most prevalent concrete panels technology (CPT) was } \\
\text { Goldflex } 100 \text { \& } 800 \text { Building System and Cemforce glass } \\
\text { reinforced concrete (GRC). } \\
\text { The second most popular technology or system is the } \\
\text { hydraform building systems (HBS) with Gauteng } \\
\text { province applying the technology in Soshanguve. } \\
\text { The third most commonly used technologies are } \\
\text { "polystyrene based with imison building" and has been } \\
\text { used widely in Gauteng province, particularly in the } \\
\text { backyard upgrading project in Zola, Soweto. } \\
\text { Moladi while sand bag technology system was the most } \\
\text { preferred technology, particularly in the Eastern Cape. }\end{array}$ & $\begin{array}{l}\text { Provinces are receptive to innovators of alternative } \\
\text { building technology (ABT) including LC, but are } \\
\text { hamstrung by subsidy constraints thereby precluding them } \\
\text { from mass scale procurement and migration to LC and } \\
\text { ABT because of the initial higher costs (Salem et al., } \\
\text { 2006). } \\
\text { No provinces have special budgetary arrangements or } \\
\text { procedures for the "procurement of ABT or application of } \\
\text { LC and or procurement" (Howell, 2011). } \\
\text { Provinces found that some of the ABT and materials } \\
\text { including LC had "hidden costs, which made their usage } \\
\text { in government subsidised houses more expensive" } \\
\text { (Koskela, Howell and Tech, 2000). } \\
\text { Unavailability of technology for large scale delivery. } \\
\text { Majority of companies remain at a prototype phase. } \\
\text { Existence of tension between the theoretical advocacy for } \\
\text { lean construction technology, alternative building } \\
\text { materials and technology, and the reality of building } \\
\text { construction industry and technology including the } \\
\text { conservative nature of the industry (Koskela, 2000). }\end{array}$ \\
\hline
\end{tabular}

\subsection{The policy and legislative debate and turn}

Since establishment, the Department of Human Settlements has provided leadership regarding several legislative proposals to accelerate the achievement of ideal human settlements for the people and strengthen the legal environment. The framing and oversight function of policies for LIH, as presented in Table 10, 
highlights the instructive nature of policy and legislation in facilitating transitions towards enhanced housing performance and delivery. Creating an enabling and developmental environment for housing provision and delivery is a necessary but not a sufficient condition for enhanced LIH spatial planning and settlement functioning as depicted from Table 10, in which case we can deduce that in South Africa several role players exist that play pivotal roles and functions in advancing the cause and concern of low-income earners in South Africa; yet, LIH challenges still persist. Housing delivery and provision is therefore a collaborative action and lean construction technology transfer must be undertaken cognizant of these realities (Holweg, 2007; Bajjou et al., 2017). LIH is a contested terrain in which various stakeholders interact in complex ways, as illustrated in Table 11, with respect to LIH role players and their functions in South Africa.

Table 10. Policy framework governing shelter/housing construction in South Africa.

\begin{tabular}{|c|c|}
\hline Housing Policy and Strategy & Headline Provisions \\
\hline Housing Act, 1997 & $\begin{array}{l}\text { 1). "Facilitates migration towards sustainable housing } \\
\text { development process and stipulates general principles } \\
\text { applicable to housing development including LIH"; } \\
\text { 2). "Categorises the functions of national, provincial and local } \\
\text { government in respect of housing development; and } \\
\text { articulates the financial arrangements with respect to national } \\
\text { housing programmes". } \\
\text { "Section } 2 \text { of the Housing Act, } 1997 \text { compels all three spheres } \\
\text { of government to prioritise the needs of the LIH groups in } \\
\text { respect of housing development". }\end{array}$ \\
\hline Social Housing Act, 2008 (Act 16 of 2008) & $\begin{array}{l}\text { 1). "Provides for the establishment of the Social Housing } \\
\text { Regulatory Authority (SHRA) to regulate all social housing } \\
\text { institutions obtaining or having obtained public funds, and it } \\
\text { allows for the undertaking of approved projects by other } \\
\text { delivery agents with the benefit of public money". } \\
\text { 2). "Gives statutory recognition to social housing institutions } \\
\text { and provides for matters connected therewith. Social housing } \\
\text { is however, characterised by a patchwork of policies, findings } \\
\text { and institutions that neither supports the growth of the sector } \\
\text { nor allows for proper regulation and monitoring of funding } \\
\text { and policy". } \\
\text { 3). "In April 2011, the SHRA launched the Social Housing } \\
\text { Accreditation Register and issued accreditation certificates to } \\
18 \text { social housing institutions". }\end{array}$ \\
\hline Human Settlements Vision 2030 & $\begin{array}{l}\text { 1). "Envisages total eradication of backlogs of more than } 2,1 \\
\text { million housing units, which translates into about } 12,5 \text { million } \\
\text { people". } \\
\text { 2). "Under Vision } 2030 \text { 's framework, most South Africans } \\
\text { will have affordable access to services and quality } \\
\text { environment, instead of living in isolation in the periphery of } \\
\text { cities. New developments throughout the country will break } \\
\text { away from old patterns and significant progress will be made } \\
\text { in retrofitting existing settlements". }\end{array}$ \\
\hline Social Contract for Rapid Housing Delivery & $\begin{array}{l}\text { 1). "Was signed in September } 2005 \text { during the Housing } \\
\text { Indaba in Cape Town". } \\
\text { 2). "The contract was signed by the then Department of } \\
\text { Housing, provincial housing departments, national housing } \\
\text { institutions and private stakeholders that form part of the } \\
\text { supply value chain in the delivery of housing". }\end{array}$ \\
\hline Inclusionary Housing Policy & $\begin{array}{l}\text { 1). "The New Economic Growth Path has identified energy, } \\
\text { transport, roads, water, communication and housing as key } \\
\text { areas in its strategy to fast-track sustainable growth, } \\
\text { employment and equity creation". } \\
\text { 2). "Is being implemented through the Presidential } \\
\text { Infrastructure Coordinating Committee (PICC)". }\end{array}$ \\
\hline
\end{tabular}

Sources: (National Department of Human Settlements, 2010; The Presidency, 2014; Tshangana, 2018).

Interventions and initiatives to address LIH have to take cognizance of the multiple agencies, actors and disciplines impacting and impacted by the housing sector, as illustrated in Table 10, if the efforts are to tackle holistically, effectively and efficiently the LIH agenda matters in South Africa that are complex, dynamic and multi-dimensional. In any case, scaling up full LC application in the sector requires capacity building and training of all stakeholders involved in LIH delivery (Ashworth and Perrera, 2015). However, 
what is encouraging is that despite challenges and issues regarding the fragmented and inadequate application of LC to benefit the low-income sector, the government and non-state sectors have an appetite for experimenting and implementing alternative construction technologies aimed at addressing the changing housing needs of the low-income group in South Africa.

Table 11. LIH role players and their functions in South Africa.

\begin{tabular}{l|l}
\multicolumn{1}{c|}{ Role player } & \multicolumn{1}{c}{ Function and or mandate } \\
\hline $\begin{array}{l}\text { National Housing Finance } \\
\text { Corporation (NHFC) }\end{array}$ & $\begin{array}{l}\text { Established in } 1996 \text { to mobilise housing development finance from non-state sectors. } \\
\text { Facilitates the provision and allocation of funding in promotion of sustainable human } \\
\text { settlements and the eradication of informal settlements. } \\
\text { The workflow process enables targeted beneficiaries to form a housing-support organisation } \\
\text { People's Housing Process (PHP) } \\
\text { that plays an oversight role with respect to organisational, technical and administrative } \\
\text { support. }\end{array}$ \\
Women in Housing (WIH) & $\begin{array}{l}\text { The National Women Build (NWB) aims at advancing the spirit of volunteerism as well as } \\
\text { public-private partnership (PPP) in LIH provision and delivery. } \\
\text { WIH supports the integration of women into the built environment sectors with explicit } \\
\text { support for initiatives relating to LIH infrastructure and service delivery, the growth and } \\
\text { development of the construction industry and, in particular, housing/building sector }\end{array}$ \\
Youth Build (YB) & $\begin{array}{l}\text { The Youth Build South Africa (SA) programme provides for linkages and connections within } \\
\text { the LIH network and innovation system with respect to pilot and demonstration projects. } \\
\text { YB's approach was piloted in Ivory Park, Midrand, in Gauteng and has been rolled out to } \\
\text { other parts of the country. }\end{array}$
\end{tabular}

\subsection{Reconciling the LC technology paradigm with budgeting realities}

Tackling LIH is incomplete without an understanding of the financial strategies and provisions as revealed in Table 12 that presents the Budget of the Department of Human Settlements 2018/2019. The budgetary allocations are split between administration, "Human Settlements Policy, Strategy and Planning, Human Settlements Delivery Support and Housing Development Finance" (Tshangana, 2018).

The budgetary allocation for the human settlements department is of approximately R3o billion (Table 12). Over 93\% of the budgetary allocation is ring fenced housing development finance. The remaining 7\% is shared between administration requirements and Human Settlements Policy, Strategy and Planning. Making stronger use of the LC approaches for LIH housing will result in more units being delivered as compared to using traditional construction methods. "Part of Lean's attractiveness to construction has been its use of elemental and therefore, low-cost tools" (Lim et al., 2011). It is critical to realize that the Department of Human Settlements implements the housing delivery in partnership with the private sector and construction contractors. These contractors can only adopt lean construction provided that the philosophy of LC is well understood and the risk associated with the switch from the existing methods to the new method is low. This is because the "construction industry has a very thin operating profit margin that ranges from 2-5\%" (Trivedi and Kumar, 2014). In implementing LIH ABT, LC and
CC adaptive and resilient settlement initiatives and interventions, there needs to be a "compelling reason for any company to consider adopting major if not radical building and construction operational technologies and initiatives" (Holweg, 2007). There are three interrelated building and settlement construction factors which contractors may find important, namely:

1). "Wasted time is very high in the housing and building construction sector" and Koskela (2011) "suggests that $66 \%$ of on-site labour performs nonvalue activities and $10 \%$ of project materials are wasted" (Koskela, 2011; Zheng et al., 2017). "Decreasing waste accumulation on project construction sites leads to a competitive advantage in cost and schedule management" (Wang and Ma, 2013; Selkämaa, 2018).

2). There are studies confirming that "average profits in the construction industry are $3 \%$ for contractors" (Sieng, 2012). According to Wang and Ma (2013) "an increase of $10 \%$ productivity in a construction/building firm in which labour (i.e. the payroll content/component) is $35 \%$ of total revenue will result in a doubling of the net profit, if the LC approach is correctly applied". Given the "high amount of waste associated with traditional building/construction approaches, it is probable that a firm can achieve this with the LC approach" (Wang, 2014).

3). On the long-term, contractors are usually keen to explore options at the end of their careers or towards the end of a project life-cycle. "If an investor or contractor has a business that does not demand their full-time attention (i.e. has employees who can work independently on most tasks) then he or she will have a 
business that can be marketed, sold and is tradable on the market" (Lin et al., 2015). "If they do not have such a competitive construction business, then they have a job and nothing to sell above the market price of its assets less its liabilities" (Gao and Low, 2014). With respect to this, construction business will always trade off the long-term benefits offered by LC in preference to the tried and tested conservative traditional construction methods as a way of risk minimization and mitigation.

Overall, the adoption and popularization of LC approach in LIH would adequately lead to the support of the implementation of the "Social Contract for Rapid Housing Delivery (SCRHD), which was conceptualised to support the implementation of government's Breaking New Ground (BNG) 2004 strategy" (National Department of Human Settlements, 2010). BNG was launched with the aim to accelerate the delivery of housing (i.e. LIH included) as a key strategy to fight poverty and reduce housing settlements inefficiencies on the market. Indeed, such a quantum leap is appreciated in a context in which the need to bolster the comprehensive housing plan (CHP) for the development of Integrated Sustainable Human Settlements“ (as spelt out in the Breaking New Ground strategy) is aimed at eradicating informal settlements in South Africa in the shortest possible time" (National Department of Human Settlements, 2015).

Table 12. Department of Human Settlements Budget 2018/2019.

\begin{tabular}{|c|c|c|c|c|c|c|c|}
\hline Programmes & \multicolumn{3}{|c|}{ Audited outcome } & $\begin{array}{c}\text { Adjusted } \\
\text { appropriation }\end{array}$ & \multicolumn{3}{|c|}{$\begin{array}{l}\text { Medium-term expenditure estimates } \\
\text { indicative }\end{array}$} \\
\hline Total Allocation R`000 & $2014 / 2015$ & $2015 / 2016$ & $2016 / 2017$ & $2017 / 2018$ & $2018 / 2019$ & $2019 / 2020$ & $2020 / 2021$ \\
\hline Administration & 433,080 & 411,074 & 420,897 & 457,665 & 442,650 & 471,546 & 502,671 \\
\hline $\begin{array}{l}\text { Human Settlements } \\
\text { Policy, Strategy and } \\
\text { Planning }\end{array}$ & 78,703 & 75,738 & 86,600 & 93,573 & 89,781 & 95,966 & 102,611 \\
\hline $\begin{array}{l}\text { Human Settlements } \\
\text { Delivery Support }\end{array}$ & 133,712 & 120,796 & 151,742 & 217,302 & 246,005 & 261,045 & 329,824 \\
\hline $\begin{array}{l}\text { Housing Development } \\
\text { Finance }\end{array}$ & $28,712,737$ & $29,426,936$ & $29,927,992$ & $32,695,760$ & $31,577,280$ & $32,859,348$ & $34,851,058$ \\
\hline Total & $29,358,232$ & $30,034,544$ & $30,587,231$ & $33,464,300$ & $32,355,716$ & $33,687,905$ & $35,786,164$ \\
\hline
\end{tabular}

Source: Tshangana, 2018.

3.7. Towards a roadmap research and implementation agenda for resolving LIH challenges in South Africa

Considering the preceding sections, one can argue that the (re)solution of LIH in South Africa requires an updated and robust research and implementation roadmap. Such an intervention should assume that LIH is prioritized as an intervention area, targets are set making use of "the last planner LC approach" and the integrative nature of the complete and total housing approach is fully optimized. Developing a LIH and LC transition and migration plan is fundamental to realising a better performing and adept LIH sector in South Africa as illustrated in Table 13, which presents LC inspired research and implementation roadmap. The transition from the current inadequate approaches to addressing LIH backlogs and deficits "blues" into an integrated and sustainable human settlements delivery strategy requires structured approach linked to the policy, legislative and human settlement internal and external factors (Table 12). At the same time, the development of an innovative construction and leadership academy driven by a research observatory is critical in providing LIH settlements backlog and deficit strategy intelligence to overcome emerging and emergent challenges. The role of partnerships and collaboration 82 in tackling housing challenges in South Africa cannot be over-emphasized.

\subsection{Strengths and limitations}

The LC and ABT innovation options and perspectives in the context of the reality to $\mathrm{CC}$ proof LIH settlements offered within this study highlights to academics, researchers, policy makers and practitioners the importance of seeking to find new, different, alternative, disruptive and innovative ways to overcoming LIH delivery and provision constraints.

This can potentially enable practitioners, project managers, clients and decision-makers to consider LC and ABT and construction techniques/technologies in the way in which LIH building and construction resources/materials as well as services are procured, implemented and managed in advancing sustainable, inclusive, resilient and integrated housing and related construction projects, and thus improve desired project outcomes. Overall, this paper is conceptual and makes a case for further empirical research using Agreement certification of South African Bureau of Standards ((SABS) as well as the "National Home Builders Registration Council's" (NHBRC) to validate the performance of LC and ABT and advanced construction techniques, low-cost building/construction materials in practice. 
Low-Income Housing Backlogs and Deficits "Blues" in South Africa.

What Solutions Can a Lean Construction Approach Proffer?

Journal Settlements and Spatial Planning, vol. 10, no. 2 (2019) 71-88

\subsection{Implications or recommendations}

Emanating from this discussion, several recommendations and suggestions can be advanced regarding moving forward the $\mathrm{LIH}$ provision and delivery set-up in South Africa. While LIH, LC and ABT similar and related findings resonate from studies and findings from other countries (Koskela et al., 2000; Ogunbiyi et al., 2014; Oldfield and Greyling, 2015; Sarhan et al., 2017), the particular and peculiar implications for South Africa from this review include the following:

Table 13. Low-income and LC inspired research and implementation roadmap: some insights.

\begin{tabular}{|c|c|c|c|c|c|}
\hline $\begin{array}{l}\text { Intervention } \\
\text { area (some } \\
\text { examples) }\end{array}$ & $\begin{array}{l}\text { Steering } \\
\text { mechanism }\end{array}$ & $\begin{array}{l}\text { Implementation } \\
\text { platforms }\end{array}$ & $\begin{array}{l}\text { Enabling } \\
\text { legislation }\end{array}$ & $\begin{array}{l}\text { Strategic plan } \\
\text { target }\end{array}$ & $\begin{array}{c}\text { Strategic medium-term and long-term } \\
\text { target }\end{array}$ \\
\hline 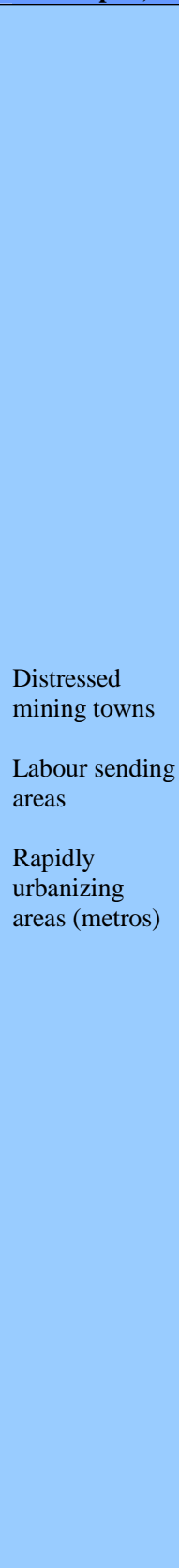 & $\begin{array}{l}\text { National } \\
\text { development plan } \\
\text { (2030) } \\
\text { Human } \\
\text { settlements vision } \\
\text { (2030) } \\
\text { National } \\
\text { infrastructure plan } \\
\text { (2011) } \\
\text { Integrated urban } \\
\text { development } \\
\text { framework (2016) } \\
\text { New urban agenda } \\
\text { (2016) } \\
\text { National spatial } \\
\text { development } \\
\text { perspective (2006) } \\
\text { - Reviewed } \\
\text { (2018) } \\
\text { National } \\
\text { transportation } \\
\text { master plan (2050) } \\
\text { United nations } \\
\text { sustainable } \\
\text { development goals } \\
\text { (2030) } \\
\text { Medium term } \\
\text { expenditure } \\
\text { framework } \\
\text { Strategically } \\
\text { located land, } \\
\text { property } \\
\text { acquisition and } \\
\text { development } \\
\text { Improvement of } \\
\text { provincial and } \\
\text { municipal contract } \\
\text { management } \\
\text { systems and } \\
\text { procedures } \\
\text { Developmental } \\
\text { capital grants strict } \\
\text { monitoring and } \\
\text { evaluation } \\
\text { compliance } \\
\text { Title deeds } \\
\text { restoration grant } \\
\text { Emergency } \\
\text { housing grant }\end{array}$ & $\begin{array}{l}\text { Housing } \\
\text { development } \\
\text { agency (HAD) } \\
\text { Social housing } \\
\text { regulatory } \\
\text { authority (SHRA) } \\
\text { capacity grants } \\
\text { National home } \\
\text { builders } \\
\text { registration council } \\
\text { (NHBRC) } \\
\text { contractor training } \\
\text { and support } \\
\text { National urban and } \\
\text { reconstruction } \\
\text { housing agency } \\
\text { (NURCHA) } \\
\text { National housing } \\
\text { finance } \\
\text { corporation } \\
\text { (NHFC) financial } \\
\text { support } \\
\text { Targeted } \\
\text { procurement } \\
\text { related to women, } \\
\text { youth, military } \\
\text { Veterans and } \\
\text { persons living with } \\
\text { disabilities } \\
\text { Green low-income } \\
\text { construction } \\
\text { methods and } \\
\text { projects }\end{array}$ & $\begin{array}{l}\text { Finalisation of } \\
\text { property } \\
\text { practitioners bill } \\
\text { Housing } \\
\text { consumers } \\
\text { protection } \\
\text { measures } \\
\text { amendment bill } \\
\text { Home loans and } \\
\text { mortgage } \\
\text { disclosure } \\
\text { amendment bill } \\
\text { Human } \\
\text { settlements } \\
\text { development bank } \\
\text { bill } \\
\text { Development of } \\
\text { the human } \\
\text { settlements code } \\
\text { Amendment of the } \\
\text { housing act to } \\
\text { human settlement } \\
\text { legislation } \\
\text { Amendment of the } \\
\text { prevention of } \\
\text { illegal evictions } \\
\text { and unlawful } \\
\text { occupation of Law } \\
\text { Act } \\
\text { Revision of the } \\
\text { social housing } \\
\text { policy and } \\
\text { regulations }\end{array}$ & $\begin{array}{l}\text { Develop a } \\
\text { comprehensive } \\
\text { and integrated } \\
\text { human } \\
\text { settlements } \\
\text { legislation } \\
\text { Provide } \\
\text { integrated } \\
\text { information and } \\
\text { communication } \\
\text { technology } \\
\text { services } \\
\\
\text { Establish and } \\
\text { strengthen } \\
\text { partnerships in } \\
\text { support of the } \\
\text { delivery of low } \\
\text { income/informal } \\
\text { settlements } \\
\text { housing } \\
\text { upgrading } \\
\text { projects }\end{array}$ & $\begin{array}{l}\text { Approved low income/informal } \\
\text { settlements housing upgrading and } \\
\text { development plan (HSDG funded) } \\
\text { Development of national human } \\
\text { settlements development plan complete } \\
\text { with a national LIH backlogs and deficit } \\
\text { reduction/mitigation plan } \\
\text { Development of urban settlement } \\
\text { development plan for metropolitan } \\
\text { municipalities (USDG funded) complete } \\
\text { with a municipal LIH backlogs and } \\
\text { deficit reduction/mitigation plan } \\
\text { Provide implementation support on the } \\
\text { delivery of LIH projects } \\
\text { Establishment of project readiness } \\
\text { matrix and implementation scheme (i.e. } \\
\text { covering LIH backlogs/deficits, informal } \\
\text { settlements upgrading plans and } \\
\text { programmes) implementation in } 9 \\
\text { provinces and } 8 \text { metros } \\
\text { Provide comprehensive and integrated } \\
\text { support in the implementation of LIH } \\
\text { backlogs/deficits reduction/mitigation } \\
\text { programme, subsidy programme, private } \\
\text { affordable rental housing, and social } \\
\text { programme housing9 provinces and } 8 \\
\text { metros } \\
\text { Multi-year land assembly plan for LIH } \\
\text { backlogs/deficits and informal } \\
\text { settlements upgrading plan reviewed to } \\
\text { incorporate pre-post } 1994 \text { title deeds } \\
\text { restoration programme tenure realities } \\
\text { Establishment of a housing programme } \\
\text { scholarship for next generation of } \\
\text { experts in sector, innovative construction } \\
\text { leadership academy and innovative } \\
\text { construction observatory and futures } \\
\text { research centre }\end{array}$ \\
\hline
\end{tabular}

1). The need to continuously monitor, evaluate and review the housing policy and regulatory set-up relevancy in addressing low-income housing deficits and backlogs with the aid of clearly developed LC led indicator framework (i.e. perhaps taking the dashboard reporting system) is vital in improving integrated LIH delivery monitoring systems in South Africa).

2). Promoting and supporting LIH pilot and demonstration projects/schemes, in which full LC, ABT and $\mathrm{CC}$ resilient $\mathrm{LIH}$ is an essential hallmark in the 
quest to have a catalytic LC uptake and roll-out of alternative approaches, technologies and models for addressing the gamut of concerns that LIH's previous, current, emerging and future beneficiaries can share or have.

3). The housing sector is an industry that has immense potential for growing opportunities for skills and knowledge transfer making use of the LC, ABT and $\mathrm{CC}$ resilient settlement framework to advance benefits to all sectors of industry, including communities.

4). It is essential that the full value chain of research is achieved through the implementation of transformative LC, ABT and CC resilient settlement projects in South Africa. This is because housing delivery and implementation is a collaborative process that requires input from both public and non-public sectors.

5). The need for continued $R \& D$ with respect to $\mathrm{LC}, \mathrm{ABT}$ and $\mathrm{CC}$ resilient settlements covering urban and rural areas and including areas under traditional leadership constitutes fields for further investment and exploration. Generating the appropriate mix of packages that apply across scale and spheres of government is an essential component in developing a turn-around strategy for massive upscale and uptake of LC, ABT and CC resilient settlements, which is necessary to facilitate the translation of these indicated initiatives into success. The role of academia and research institutes in supporting the theory and practice of LIH cannot be over-emphasised.

6). Political leadership and support is necessary in the promotion and roll-out of new and disruptive LIH technologies, as discussed in this paper. Ultimate success will hinge on advanced spatial planning that promotes well located and sited LIH settlements, supportive LIH infrastructure and services provision, resource and budget provision, skills and capacity building, awareness and sensitisation workshops as well as the implementation of a critical mass of such LIH projects to change mindsets and improve uptake and practical implementation acceptance in the construction sector.

\section{CONCLUSION}

The "human settlements sector in South Africa remains one of the most challenging areas in the social and economic environment" (National Department of Human Settlements, 2015; Ballard and Rubin, 2017; Tomlinson, 2017). This is partly because solving the housing problem has been seen as a fight against a moving average which is further complicated by the fact that housing problem fits the requirements of a "wicked problem" that requires multiple, non-conventional approaches and solutions in (re)solving the matters germane to the sector (Dearnaley, 2018). Realising the right of every citizen to a home involves far more than the delivery of a subsidised house. Innovations in housing finance, construction/building technology and materials, subsidy mechanisms and institutional arrangements driven by the lean construction framework of analysis "is required to find appropriate responses to changing circumstances in the housing sector" (Bajjou et al., 2017; Cirolia et al., 2017). Allowing, for example, municipalities to experiment with LC, alternative smart LC inspired housing approaches, innovation and ABT and advanced construction and building technologies to "housing policy implementation, even if only on a medium-term pilot basis, is likely to inform and stimulate the ongoing refinement of public housing policy to meet changing market conditions and household needs" (Huchzermeyer,2014; Sarhan et al., 2017). Combining LC with ABT within the context of climate change induced flood risks vulnerabilities is an important plank in retrofitting and building resilient settlements in both urban and rural South Africa. Exploring and conducting pilot tests and demonstrations with respect to $\mathrm{CC}, \mathrm{ABT}$ and LC LIH spatially resilient and proofed sustainable human settlements is one way towards contributing to the sustainable development goals (SDGs), 2015, New Urban Agenda (NUA), 2016 as well as meeting the National Development Plan (NDP) 2030 goal of moving and transiting to a low carbon green economy for South Africa. The conceptual framework sketched in this paper constitutes an important framework for further guiding human settlements development in South Africa.

\section{ACKNOWLEDGEMENTS}

Competing Interest: The author has no competing interest to declare.

Funding: The University of Venda Directorate for Research and Innovation for research support that enabled the publication of this article.

Disclaimer: The views expressed in the submitted article are the author's views and not the official position of the employer or project funder.

\section{REFERENCES}

Ashworth A., Perera S. (2015), Cost studies of buildings. Routledge.

Antunes R., Gonzalez V. (2015), A production model for construction: A theoretical framework. Buildings, 5, 209-228. DOI: doi:10.3390/buildings5010209.

Azar A. T. (2012), System dynamics as a useful technique for complex systems. International Journal of Industrial and Systems Engineering, 10(4), 377-410. DOI:https://doi.org/10.1504/IJISE.2012.046298.

Bajjou M. S., Chafi A., En-nadi A. (2017), A Comparative Study between Lean Construction and the Traditional Production System. International Journal of 
Low-Income Housing Backlogs and Deficits "Blues" in South Africa.

What Solutions Can a Lean Construction Approach Proffer?

Journal Settlements and Spatial Planning, vol. 10, no. 2 (2019) 71-88

Engineering Research in Africa, 29, 118132.DOI:10.4028/www.scientific.net/JERA.29.118

Bajjou M. S., Chafi A., Ennadi A., El Hammoumi M. (2017), The Practical Relationships between Lean Construction Tools and Sustainable Development: A literature review. Journal of Engineering Science and Technology Review, 10(4), 170-177. DOI: 10.25103/jestr.104.20.

Bajjou, M. S., Chafi, A. (2019), Identifying and Managing Critical Waste Factors for Lean Construction Projects. Engineering Management Journal, 1-12.DOI: 10.1080/10429247.2019.1656479

Ballard G. (1999), Improving work flow reliability. Proceedings IGLC-7, Conference of International Group for Lean Construction, Univ. California, Berkeley, CA, 275-286.

Ballard R., Rubin M. (2017), A 'Marshall Plan' for human settlements: how megaprojects became South Africa's housing policy. Transformation: Critical Perspectives on Southern Africa, 95(1), 1-31. DOI:10.1353/trn.2017.0020.

Bredenoord J. (2017), Sustainable building materials for low-cost housing and the challenges facing their technological developments: examples and lessons regarding bamboo, earth-block technologies, building blocks of recycled materials, and improved concrete panels. Journal of Architectural Engineering Technology, 6(1), 1-11. DOI: 10.4172/21689717.1000187.

Caruso M. C., Menna C., Asprone D., Prota A., Manfredi G. (2017), Methodology for life-cycle sustainability assessment of building structures. Structural Journal, 114(2), 323-336.

Chakwizira, J., Bikam, P. (2007), Sustainability and construction materials in housing and infrastructure: a pro-poor approach. Journal of Construction, 1(1), 2026.

Chévez P. J., Martini I., Discoli C. (2019), Methodology developed for the construction of an urban-energy diagnosis aimed to assess alternative scenarios: An intra-urban approach to foster cities' sustainability. Applied Energy, 237, 751-778. DOI:https://doi.org/10.1016/j.apenergy.2019.01.037.

Cirolia L. R., Görgens T., van Donk M., Smit W., Drimie S. (Eds.) (2017), Upgrading informal settlements in South Africa: Pursuing a partnershipbased approach. Juta and Company (Pty) Ltd.

Constitution of the Republic of South Africa (1996), Constitution, Pretoria, South Africa, URL Government of South Africa: https://www.gov.za/documents/constitution/constituti on-republic-south-africa-1996-1. Accessed on 28.05.2019

CSIR (Council for Scientific and Industrial Research) (2011), Settlements typology. PowerPoint Presentation prepared for the National Planning Commission, Treasury URL:https://csp.treasury.
gov.za/Resource\%2O_Centre/Conferences/Documents /Urbanization\%2oReview\%2oPapers/Paper\%206\%20\%20Analysis\%20of\%20HS\%2oProgramme.pdf. Accessed on 28.05.2019.

DEA (2011), National Strategy for Sustainable Development and Action Plan (NSSD) 2011-2014. Department of Environmental Affairs, Pretoria, South Africa, DEA URL: https://www.environment.gov.za /sites/default/files/docs/sustainabledevelopment_actio nplan_strategy.pdf. Accessed on 28.05.2019

Dearnaley P. (2018), Health, social care and housing: facing a wicked problem, Housing, Care and Support, Vol. 21 Issue: 3/4, pp.65-68, https://doi.org/10.1108/ HCS-12-2018-029.

Department of Housing (1994), Housing White Paper, Pretoria, South Africa, DHS URL: http://www.dhs.gov.za/sites/default/files/legislation/P olicies_Housing_White_Paper.pdf. Accessed on 28.05.2019

Department of Housing (2000), National Housing Code, Pretoria, South Africa, DHS URL: http://www.dhs.gov.za/content/national-housingcode-2009. Accessed on 28.05.2019

Department of Housing (2004), "Breaking New Ground" - The Comprehensive Plan for the Development of Sustainable Human Settlements, Pretoria, South Africa, DHS URL: http://www.dhs.gov.za/sites/default/files/documents/ 26082014_BNG2004.pdf. Accessed on 28.05.2019.

Daniel E. I., Pasquire C., Dickens G., Ballard H. G. (2017), The relationship between the Last Planner $\AA$ System and collaborative planning practice in UK construction. Engineering, Construction and Architectural Management, 24(3), 407-425.DOI: 10.1108/ECAM-07-2015-0109.

Dayaratne R., Kellett P. (2008), Housing and homemaking in low-income urban settlements: Sri Lanka and Colombia. Journal of Housing and the Built Environment, 23 (1), 53-70. DOI:https://doi.org/10. 1007/s10901-007-9099-0.

Du Plessis C. (2005), Action for sustainability: preparing an African plan for sustainable building and construction. Building Research \& Information, 33(5), 405-415. DOI:https://doi.org/10.1080/0961321050 0218974.

Durakovic B., Demir R., Abat K., Emek C. (2018), Lean Manufacturing: Trends and Implementation Issues. Periodicals of Engineering and Natural Sciences (PEN), 6(1), 130-143.DOI: /10.21533/pen.v6i1.45.

Fewings P., Henjewele C. (2019), Construction project management: an integrated approach. Routledge.

Ganiyu B. O. (2016), Strategy to enhance sustainability in affordable housing construction in South Africa (Doctoral dissertation, Cape Peninsula University of Technology). 
Foong D., Mitchell P., Wagstaff N., Duncan E., McManus P. (2017), Transitioning to a more sustainable residential built environment in Sydney?. Geo: Geography and Environment, 4(1), 1-11, eooo33.

Gao G., Low S. P. (2014), The Toyota Way Model: An Alternative Framework for Lean Construction. Total Quality Management \& Business Excellence, 25 (5-6) 664-682. DOI: 10.1080/14783363.2013.820022.

Goetz G., Schaeffler A. (2015), Conundrums in implementing a green economy in the Gauteng CityRegion. Current Opinion in Environmental Sustainability, 13, 79-87. DOI: https://doi.org/10.1016/ j.cosust.2015.02.005.

Holweg M. (2007), The genealogy of lean production. Journal of Operations Management, Vol. 25 (2), 420437. DOI: https://doi.org/10.1016/j.jom.2006.04.001.

Howell G. (2011), Book Review: Build Lean: Transforming construction using Lean Thinking by Adrian Terry \& Stuart Smith. Lean Construction Journal, 3-8.

Huang Y. (2012), Low-income housing in Chinese cities: policies and practices. The China Quarterly, 212, 941-964. DOI: https://doi.org/10.1017/So3057410 12001270.

Huchzermeyer M. (2014), Humanism, creativity, and rights: Invoking Henri Lefebvre's right to the city in the tension presented by informal settlements in South Africa today. Transformation: Critical Perspectives on Southern Africa 85(1), 64-89. DOI: 10.1353/trn.2014.0026.

Ibem E. O., Aduwo E. B. (2013), Assessment of residential satisfaction in public housing in Ogun State, Nigeria. Habitat International, 40, 163-175. DOI: https://doi.org/10.1016/j.habitatint.2013.04.001.

Roberts D., O'Donoghue S. (2013), Urban environmental challenges and climate change action in Durban, South Africa. Environment and Urbanization, 25(2), 299-319. DOI: 10.1177/0956247813500904.

Koskela L. (1992), Application of the new production philosophy to the construction industry. Stanford, USA, Stanford University, Technical Report 72.

Koskela L. (2011), Fifty Years of Irrelevance: The Wild Goose Chase of Management Science. Lean Construction Journal, IGLC Special Issue, 1-11. http://tinyurl.com/ma7rdmn.

Koskela L., Howell G. (2000), Reforming project management: the role of Lean Construction Proc., IGLC-8th Conf. of Int. Group for Lean Construction, 8 Brighton, Brazil.

Koskela L., Ferrantelli A., Niiranen J., Pikas E., Dave B. (2018), Epistemological Explanation of Lean Construction. Journal of Construction Engineering and Management, 145(2), 04018131.DOI:10.1061/(ASCE) CO.1943-7862.0001597.

Lee J., Park M., Lee H. S., Kim T., Kim S., Hyun H. (2017), Workflow dependency approach for modular building construction manufacturing process using
Dependency Structure Matrix (DSM). KSCE Journal of Civil Engineering, 21(5), 1525-1535. DOI: https://doi. org/10.1007/s12205-016-1085-1.

Lim B.T.H., Ling F.Y.Y., Ibbs W.C.,Raphael B., Ofori G. (2011), Empirical Analysis of the Determinants of Organizational Flexibility in the Construction Business. Journal of Construction Engineering and Management, 137(3) 225-237. DOI: http://dx.doi.org/10.1061/(ASCE)CO.1943-7862. 0000272.

Lin Y., Zhang X., Geertman S. (2015), Toward smart governance and social sustainability for Chinese migrant communities. J. Clean. Prod. 107 (16), 389-399. DOI: https://doi.org/10.1016/j.jclepro.2014.12. 074.

Oldfield S., Greyling S. (2015), Waiting for the state: a politics of housing in South Africa. Environment and Planning A: Economy and Space, 47(5), 1100-1112. DOI: https://doi.org/10.1177/0308518X15592309.

Oguntona O. A., Aigbavboa C. O., Mulongo G. N. (2019), An Assessment of Lean Construction Practices in the Construction Industry. In: Charytonowicz J., Falcão C. (eds) Advances in Human Factors, Sustainable Urban Planning and Infrastructure. AHFE 2018. Advances in Intelligent Systems and Computing, 788, 524-534. Springer, Cham. DOI https://doi.org/10.1007/978-3-319-94199-8_51.

Ogunbiyi O., Goulding J. S., Oladapo A. (2014), An empirical study of the impact of lean construction techniques on sustainable construction in the UK. Construction innovation, 14(1), 88-107. DOI: 10.1108/CI-08-2012-0045.

Martinez E. (2016), Exploring the use of the Lean Principles to deliver Affordable Housing in Latin America. Doctor of Philosophy dissertation. University of California. Berkeley.

Marzouk M., Metawie M. (2014), Framework for sustainable low-income housing projects in Egypt. In Issa R., Issa P. E., Flood I. (eds.), Computing in Civil and Building Engineering Edited, 1960-1968. DOI: https://doi.org/10.1061/9780784413616.243.

Moaveni S., Banihashemi S. Y., Mojtahedi M. (2019), A Conceptual Model for a Safety-Based Theory of Lean Construction. Buildings, 9(1), 23, 1-11. DOI: https://doi.org/10.3390/buildings9010023.

Msindo E. (2017), Housing backlog: Protests and the demand for Housing in South Africa powerpoint presentation, Johannesburg: Public Service Accountability Monitor (PSAM), Pretoria, South Africa.

Myers D. (2016), Construction economics: A new approach. Routledge.

National Department of Human Settlements (2010), Updating existing knowledge on the usage of alternative building technologies in housing construction, Pretoria, South Africa, DHS URL: http://www.dhs.gov.za/sites/default/files/documents/ publications/Human_Settlements_Review_A.pdf. Accessed on 28.05.2019. 
National Department of Human Settlements (2015), Towards a Policy Foundation for the Development of Human Settlements Legislation., Pretoria, South Africa, DHS URL: http://www.dhs.gov.za/content/2017-humansettlements-summit. Accessed on 28.05.2019.

Ndaba D. (2008), South Africa's affordable-housing programme is maturing, but the delivery pressures are mounting. Engineering News. 11 July 2008, Pretoria, Engineering News URL: https://www. engineeringnews.co.za/article/affordablehousingprogramme-is-maturing-but-the-delivery-pressuresare-mounting-2008-07-11.Accesses on 28.05.2019. Nguyen T. T., Bonetti J., Rogers K., Woodroffe C. D. (2016), Indicator-based assessment of climatechange impacts on coasts: A review of concepts, methodological approaches and vulnerability indices. Ocean \& Coastal Management, 123, 18-43. DOI: https://doi.org/10.1016/j.ocecoaman.2015.11.022.

Rane A. B., Sunnapwar V. K., Rane S. (2016), Strategies to overcome the HR barriers in successful lean implementation. International Journal of Procurement Management, 9(2), 223-247. DOI: https://doi.org/10.1504/IJPM.2016.075266.

Reddy P. S. (2016), The politics of service delivery in South Africa: The local government sphere in context, The Journal for Transdisciplinary Research in Southern Africa, 1, 1-8.

Ross N., Bowen P. A., Lincoln D. (2010), Sustainable housing for low-income communities: lessons for South Africa in local and other developing world cases. Construction Management and Economics 28 (5), 433-449. DOI: https://doi.org/10.1080/0144619 0903450079 .

Salem M., Solomon J., Genaidy A., Minkarah, I. (2006), Lean Construction: From Theory to Implementation. Journal of Management in Engineering, 22(4). 168-175. DOI: https://doi.org/ 10.1061/(ASCE)0742-597X.

Sarhan S., Pasquire C., King A. (2017), The concept of Institutional Waste within the Construction industry: A potential theoretical framework. Lean Construction Journal, 12-24.

Selkämaa R. (2018), Decreasing time-waste in production through digitalization. Master of Science in Technology Thesis, Aalto University, School of Engineering, Helsinki.

Schroeder G. (2014), Integrated Project Delivery Under State of Washington and Colorado CM/GC Type Contracts. Lean Construction Journal, 16-26.

Shapurjee Y., Charlton S. J. (2013), Transforming South Africa's low-income housing projects through backyard dwellings: intersections with households and the state in Alexandra, Johannesburg. Journal of Housing and the Built Environment, 28(4), 653-666. DOI: https://doi.org/10.1007/s10901-013-9350-9.
Smit W., Pieterse E., Palmer I., Parnell S. (2011), Human Settlements Growth Path. African Centre for Cities - University of Cape Town, Cape Town.

Smith R. E. (2010), Prefab architecture: A guide to modular design and construction. John Wiley \& Sons. Hoboken, New Jersey.

Smith R. E. (2014), Off-Site and Modular Construction Explained. Off-Site Construction Council, National Institute of Building Sciences. https://cdn.ymaws.com/www.nibs.org/resource/resmgr/ OSCC/OSMC_Explained.pdf. Accessed on 28.05.2019.

Souza R. (2004), Qualidade no setor da construção. In: OLIVEIRA, O.J. Gestão da qualidade, Tópicos avançados, Pioneira Thomson Learning, 199-210 [book in Spanish].

Suh Y. (2015), A global knowledge transfer network: The case of Toyota's global production support system. International Journal of Productivity and Quality Management, 15(2), 237-251. DOI: https://doi.org/ 10.1504/IJPQM.2015.067765.

Stats S. A. (2007), Community Survey, Pretoria, South Africa, Stats SA URL: https://www.statssa.gov.za/ publications/CS2007RDP/CS2007RDP.pdf. Accessed on 28.05.2019.

Stats S. A. (2009), General Household Survey, Pretoria, South Africa, Stats SA URL: http://www. statssa.gov.za/publications/Po318/Po3182009.pdf. Accessed on 28.05.2019.

Tam, V. W. (2011), Cost effectiveness of using low cost housing technologies in construction. Procedia Engineering, 14, 156-160. DOI: https://doi. org/10.1016/j.proeng.2011.07.018.

Statistics South Africa (2016), Community Survey 2016, Statistical Release, Po301, Pretoria, South Africa. http://cs2016.statssa.gov.za/wpcontent/uploads/2016/o7/NT-30-06-2016-RELEASEfor-CS-2016-_Statistical-releas_1-July-2016.pdf.

Accessed on28.05.2019.

Statistics South Africa (2018), General Household Survey 2018, Pretoria, South Africa. http://www.statssa. gov.za/publications/Po318/Po318 2018.pdf. Accessed on 28.05.2019

The Presidency (2014), Medium Term Expenditure Framework: Outcome 8: Sustainable Human Settlements and Improved Quality of Household Life. Pretoria: The Presidency. South Africa, DPME URL: https://www.dpme.gov.za/publications/Outcomes\%20 Delivery\%20Agreements/Outcome\%2008\%20Human \%20Settlement.pdf. Accessed on 28.05.2019.

Tissington K. (2011), A resource guide to housing in South Africa 1994-2010: Legislation, policy, programmes and practice, SERI, Pretoria, University Press, SERI URL: http://www.urbanlandmark. org.za/downloads/SERI_Housing_Resource_Guide_F eb11.pdf. Accessed on 28.05.2019.

Tomlinson R. (2017), Urbanization in post-apartheid South Africa. Routledge. 
Trivedi J., Kumar R. (2014), Optimisation of construction resources using lean construction technique. International Journal of Engineering Management and Economics, 4(3-4), 213-228. DOI: https://doi.org/10.1504/IJEME.2014.066941.

Tshangana M. (2018), Strategic and Annual Performance Plan Presentation to Human Settlements Portfolio Committee - 2018/19, 17th April 2018, Pretoria, South Africa, Government of South Africa URL: $\quad$ https://www.gov.za/sites/default/files/gcis_ document/201810/dhsannual-report-20172018.pdf. Accessed on 28.05.2019.

Pekuri A., Suvanto M., Haapasalo H., Pekuri L. (2014), Managing value creation: the business model approach in construction. International Journal of Business Innovation and Research, 8(1), 36-51. DOI: https://doi.org/10.1504/IJBIR.2014.058045.

Pillay J. (2017), The relationship between housing and children's literacy achievement: Implications for supporting vulnerable children. South African Journal of Education, 37(2), 1-10. DOI: https://dx.doi.org/ 10.1570o/saje.v37n2a1268.

Pheng L. S., Meng C. Y. (2018), Managing productivity in construction: JIT operations and measurements. Routledge.

Van Damme H., Houben H. (2018), Earth concrete. Stabilization revisited. Cement and Concrete Research, 114, 90-102. DOI: https://doi.org/10.1016/j.cemconres. 2017.02.035.
Vinodh S., Kumar C. V., Manjunatheshwara K. J. (2015), Development of a methodology to evaluate lean remanufacturing characteristics in a manufacturing organisation. International Journal of Services and Operations Management, 21(2), 187-199. DOI: 10.1504/IJSOM.2015.069379.

Wang J. (2014), Method and implementation of lean thinking based on the construction management model of lean. Advanced Materials Research, 912, 1648-1651. DOI: 10.4028/www.scientific.net/AMR.912-914. 1648.

Wang J., Ma R. Q. (2013), Research on the Core Method of Lean Construction Management Mode and its Implementation. Advanced Materials Research, 853, 500-505. DOI: 10.4028/www.scientific.net/AMR. 853.500 .

Womack J. P., Jones D. T., Roos D. (1990), The machine that changed the world. New York: Rawcon Associates.

Zeiderman A. (2016), Adaptive publics: building climate constituencies in Bogotá. Public Culture, 28(2 (79)), 389-413. DOI: https://doi.org/10.1215/ o8992363- 3427499.

Zheng L., Wu H., Zhang H., Duan H., Wang J., Jiang W., Dong B., Liu G., Zuo J., Song Q. (2017), Characterizing the generation and flows of construction and demolition waste in China. Construction and Building Materials, 136, 405-413. DOI: https://doi.org/10.1016/j.conbuildmat. 2017.01. 055. 